D2：日本人のコレステロール高值を積極的に治療すべきか

\title{
欧米人を対象としたエビデンスを日本人に当てはめることの危うさ： 日本人の虚血性心疾患予防における脂質低下療法
}

${ }^{1}$ 駿河台日本大学病院、 ${ }^{2}$ 日本大学医学部総合健診センター、

${ }^{3}$ 日本大学医学部内科学系循環器内科学分野

谷 樹昌 ${ }^{1,3}$ 、長尾 建 ${ }^{1,3)}$ 、久代 登志男 ${ }^{2}$ 、高橋 敦彦 ${ }^{2}$ 、平山 篤志 ${ }^{3}$

虚血性心疾患の危険因子は従来、欧米人を対象とした研究により検討されてきたが、食生活や血清 脂質濃度などの地域特性が異なることにより、我が国独自の研究が必要とされている。欧米人を対象 とした大規模介入試験では LDL-C の低下率と虚血性心疾患発生率との間に相関関係が示され、近年 では LDL-C を強力に $50 \mathrm{mg} / \mathrm{dL}$ 台まで低下させることによって、虚血性心事故発生を更に低下させる ことが示された。それらの結果をうけて米国の脂質管理ガイドライン NCEP ATP III では虚血性心疾 患のハイリスク例では LDL-C を 70mg/dL まで低下させることが推奨されている。しかしながら、日 本人に対してこの様な積極的な LDL-C 低下の有益性 (lower the better) の実証はされていない。我々 も作成班員として参加した我国の心筋梗塞 2 次予防のガイドラインでも LDL-C 管理目標は $100 \mathrm{mg} / \mathrm{dL}$ 以下という域を超えていない。近年、虚血性心疾患の 1 次予防効果を検証した低用量のプラバスタチ ンを用いた The Management of Elevated Cholesterol in the Primary Prevention Group of Adult Japanese (MEGA study)では日本人のスタチンの反応性の良好性を示した（図 1 )。

我々は国内外でスタチンの冠動脈プラーク進展抑制に関する報告をしてきた。その反響は大きく特 に国外からは欧米人を対象とした試験結果とは大幅に異なる旨の疑問が多く投じられてきた。我々の 報告を含め日本人を対象にした試験成績はスタチンの冠動脈プラーク進展抑制効果は欧米人に比較し て良好な結果を示している（図 2 )。

以上より、日本人の脂質代謝、動脈硬化進展度、あるいは薬剤の反応性は欧米人とは異なることは 明白である。日本人を対象にした確固たるエビデンスが構築されるまでは欧米のエビデンスを実地臨 床に応用するには時期尚早であると思われる。

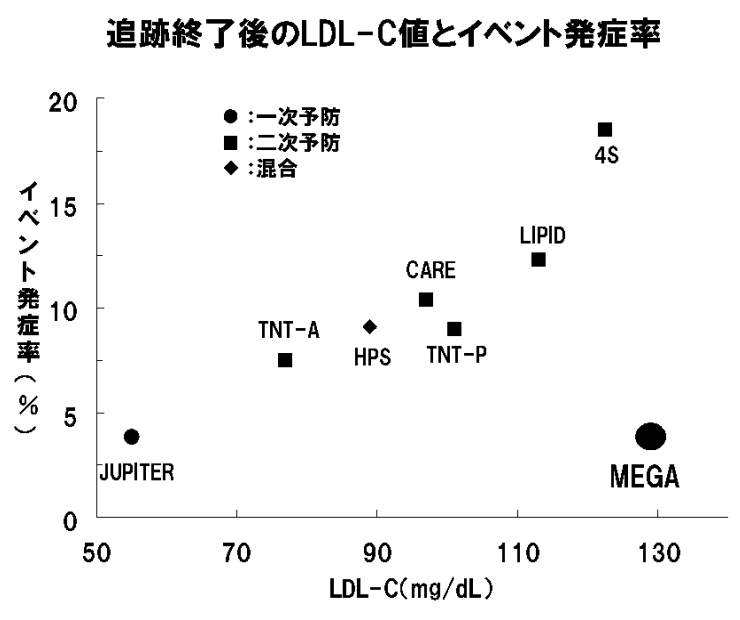

図 1
スタチンの冠動脈プラークに対する反応性

\begin{tabular}{|c|c|c|c|c|c|}
\hline & & & & & \\
\hline & $\begin{array}{l}\text { 菜㓱 } \\
\text { 投与量 }\end{array}$ & $\begin{array}{c}\mathrm{LDL} \text { 到達值 } \\
(\mathrm{mg} / \mathrm{dL})\end{array}$ & $\begin{array}{l}\text { 期間 } \\
(\text { 年) }\end{array}$ & 退㜚 & 進展 \\
\hline 欧米人を対象 & & & & & \\
\hline REVERSAL & $\begin{array}{l}\text { Atorvastatin } \\
80 \mathrm{mg}\end{array}$ & 79 & 1.5 & & \\
\hline ASTEROID & $\begin{array}{l}\text { Rosuvastatin } \\
40 \mathrm{mg}\end{array}$ & 61 & 2 & & \\
\hline 日本人を対曼 & & & & & \\
\hline TANI & $\begin{array}{l}\text { Pravastatin } \\
10-20 \mathrm{mg}\end{array}$ & 104 & 0.5 & & \\
\hline ESTABLISH & $\begin{array}{c}\text { Atorvastatin } \\
20 m g\end{array}$ & 70 & 0.5 & & \\
\hline COSMOS & $\begin{array}{c}\text { Rosuvastatin } \\
2.5-20 m g\end{array}$ & 83 & 1.5 & & \\
\hline$J A P A N-A C S$ & $\begin{array}{l}\text { Pitavastatin } \\
\text { 4mg }\end{array}$ & 81 & 1 & & \\
\hline & $\begin{array}{c}\text { Atorvastatin } \\
20 \mathrm{mg}\end{array}$ & 84 & 1 & & \\
\hline
\end{tabular}

困 2 